\title{
Gençlerin Kariyer Yaşamı Nasıl Planlanır?
}

DOI: $10.26466 /$ opus.393841

\author{
*

\section{Çağla Girgin-Büyükbayraktar ${ }^{*}$ - Şahin Kesici** ${ }^{* *}$ Hasan Bozgeyikli ***} \\ * Dr. Öğr, Ü. Selçuk Üni. Ali Akkanat Uygulamalı Bilimler Yüksek Okulu, Beyşehir / Türkiye \\ E-Posta: cagla.girgin@hotmail.com \\ ORCID: 0000-0001-8440-6320 \\ **Prof. Dr. Necmettin Erbakan Üniversitesi, Ahmet Keleşoğlu Eğitim Fakültesi, Konya / Türkiye

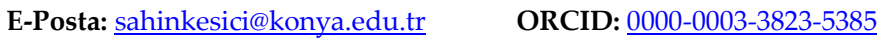 \\ *** Doç. Dr. Erciyes Üniversitesi, Eğitim Fakültesi, Kayseri / Türkiye \\ E-Posta: hbozgeyikli@erciyes.edu.tr ORCID: $\underline{0000-0002-6762-1990}$
}

\section{Öz}

Bu araştırmanın amacı, psikolojik danışmanların gençlerin kariyer yaşamı planlamasına dair görüşlerini belirlemektir. Bu çalışmada nitel araştırma tekniğinden yararlanılmıştır. Araştırma için amaçl örnekleme yöntemi kullanılmıştır. Araştırmaya yüksek lisans yapmakta olan ve kariyer danışmanlığı dersini almış psikolojik danışmanlar katılmıştır. Araştırmanın çalışma grubu 34 psikolojik danışmandan oluşmaktadır. Bu psikolojik danışmanların 20'si (\%58.87) kadın, 14'ü (\%41.13) erkektir. Psikolojik danışman olarak görev yapma yılına göre 1-9 yıl arasında dağılım göstermektedirler. 1-3 yıl arasında görev yapanlar 21 kişi (\%61.77), 4-6 yıl arasında görev yapanlar 9 kişi (\%26.47), 7-9 yıl arasında görev yapanlar ise 4 kişi (\%11.76)'dir. Araştırma verilerinin toplanmasında veri toplama yöntemi olarak yarı yapılandırılmış görüşme tekniği kullanılmıştır. Görüşme sonucu elde edilen veriler, içerik analizi tekniği ile analiz edilmiştir. Veriler yorumlanırken temalar tespit edilmiştir. Her bir tema ile ilgili kategoriler oluşturulmuştur. Araştırmada uygulanan yarı yapılandırılmış görüşme formundan elde edilen verilerin içerik analizi ile elde edilen sonuçlarında, bireylerin kariyer yaşamın planlarken; eş seçimi, iş ve meslek seçimi, kalacak yer seçimi (mesken seçimi, çevre), serbest zamanı planlama faaliyetlerinin önem kazandı̆̆ ortaya konulmuştur.

Anahtar Kelimeler: Gençler, Görüşler, Kariyer planlama, Psikolojik Danışman

OPUS @ C Uluslararası Toplum Araştırmaları Dergisi-International Journal of Society Researches ISSN:2528-9527 E-ISSN : 2528-9535

http://opusjournal.net 


\title{
How to Plan Career Life of the Youth?
}

\begin{abstract}
The purpose of this research is to determine the opinions of psychological counselors regarding the career planning of individuals. Qualitative research technique was used in this study. Purposive sampling method was used for the research. Psychological counselors, who are doing master degree and took the career counseling course, participated in the research. The study group of the research consists of 34 psychological counselors. 20 of these psychological counselors (58.87\%) are female and $14(41.13 \%)$ are male. According to the year of serving as a psychological counselor, they range from 1 to 9 years. 21 persons (61.77\%) who worked between 1-3 years, 9 persons $(26.47 \%)$ who worked between 4-6 years, and those who worked between 7-9 years are 4 people $(11.76 \%)$. Semi-structured interview technique was used as data collection method in collecting research data. The data obtained after the interview was analyzed by content analysis technique. While the data was interpreted, the themes were determined. Categories were created for each theme. In the results obtained by content analysis of the data through the semi-structured interview form applied in the research, choice of spouse, choice of job and occupation, choice of place to stay (housing choice, environment), free time planning activities were proven to be important while planning the career life of individuals.
\end{abstract}

Anahtar Kelimeler: Youth, Opinions, Career planning, Psychological counselor 


\section{Giriş}

Gençler bir çocuğun zihnini ve bedenini geride bırakır ve bir yetişkinin zihnini ve bedenini almaya başlarlar (Plotnik, 2007, s.408). Hayatın bu dönemi her bakımdan bir seçim yapma; öğrenim, meslek, dünya görüşü, din gibi hayati konularda kararlar vermeyi gerektiren bir süreç olarak yaşanır (Hökelekli, 2015, s.41). Toplum bu seçme süreci tarafından şekillendirilir. Seçim, insan hayatının temel bir sürecidir; günlük hayatta ve hayatımız boyunca, bir insan olarak kendimiz için yaptığımız seçimlerle ve başkaları tarafından yapılan seçimlerle varızdır (Foskett ve HemsleyBrown, 2001).

Gençlik yaşamla ilgili önemli kararların alındığı bir dönemdir (Dikaiou, 2000, s.20). Aynı zamanda bir yetişkin olma aşamasıdır. Yetişkin olmak için gençlerin fiziksel, duygusal, sosyal, ekonomik ve cinsel açıdan bağımsız olmaları gerekir. Kendi hayatları için sorumluluk almanın yollarını aramalıdırlar. Bununla birlikte, kendilerini yetişkin olmaya hazırlamak için, en azından kararlar vermede bilgi, beceri ve tutum kazanmaları, hedeflere ulaşmayı planlamaları ve zorluklarla baş etmeleri gerekir (Ueno, 2002). Genç insanlar kişisel planlarını yaparken geçmiş yaşantılarından, sosyal, ekonomik durumlarından, aile ve arkadaş çevrelerinden ciddi şekilde etkilenirler (Hodkinson, 1998).

Kariyer hazırlığı, gençlerin yaşam planlamasında dikkate alması gereken temel planlardır. Bu konu geçiş döneminde yani ergenlik ve yetişkinlik dönemi arasında olan insanlar için önemlidir, çünkü bir kariyer onların sosyal ve ekonomik açıdan bağımsız olmalarına izin verir (Ueno, 2002; Rogers, Creed ve Glendon, 2008). Bu süreçte gençler mesleki prototipler ile kendi rol ve becerileri arasında nasıl bir bağlantı kuracağ1 sorusuyla karşı karşıya kalır (Erikson, 1977, s. 235). Bununla birlikte kariyer seçimi artık daha fazla önem gerektiren bir konu olmuştur. Çünkü, hızla gelişen ve değişen teknolojiler bazı geleneksel meslek gruplarını ortadan kaldırmış ve farklı alanlarda uzmanlık gerektiren yeni mesleklerin ortaya çıkmasına yol açmıştır. Bireylerin tüm yaşamlarını etkileyecek olan bu seçimi yaparken, onu etkileyen tüm faktörleri araştırmak gerekir (Bandura, Barbaranelli, Caprara ve Pastorelli, 2001). İşte bu noktada erken dönem kariyer kararı verme, eğer gençler başarılı olmak istiyorlarsa, kritik önem taşır. Bu karar, bazı müfredat dışı 
etkinliklere katılmayı içerebilir; bir spor veya topluluk grubunda liderlik rolü; hedeflenen alanda profesyonellerle etkileşim kurmak ve etkileşimde bulunmak için profesyonel bir birliğe katılmak ya da gönüllü çalışma veya ilgili iş tecrübesi için bir staj üstlenmek gibi (Roulin ve Bangerter, 2013).

Gençlerin kariyer yaşamları nasıl planlanır, konusuna odaklanırken öncelikle kariyer tanımını belirginleştirmek gerekir. Kariyer; bir kimsenin yaşamının herhangi bir anında sahip olduğu tüm yaşam rollerinin gerektirdiği etkinliklerin bileşimidir. Kariyer, yaşam boyu devam eden bir süreçtir, bir meslek seçmekle veya mesleğe girmekle tamamlanmaz (Yeşilyaprak, 2011). Zunker (2008)'e göre kariyer; duygusal, bilişseldavranışsal ve kültürel ihtiyaçları dikkate alan bütünsel bir yaklaşımla incelenmelidir. Kariyer ve iş birbirinden farklıdır. Kariyer iş olarak adlandırılan insan aktiviteleri içinde ortaya çıkmış yapay bir durumdur. İş ise insanlık tarihi kadar eskidir. Diğer taraftan kariyer nispeten daha yeni yapılandırılmıştır. İş belirli bir beceri setinde uzmanlaşma gerektirir (Arulmani, 2014).

Kariyer yaşamı ya da bazılarının tercih ettiği şekilde yaşam kariyeri terimi tüm yaşam rolleri arasındaki bağlantıyı aydınlatır. İnsanlar yaşamları boyunca aynı anda birden çok rolü üstlenirler ve bir rolü başarıyla tamamlamak bir başka rolü etkiler. Bu döngü yaşam boyu sürüp gider (Zunker, 2006, s.11). Bireylerin kariyer deneyimi her zaman yaşamın bütünü bağlamında ortaya çıkar. Kariyer deneyimleri bir kişinin yaşam deneyimlerinden hiçbir zaman arındırılamaz. Bu açıdan bakıldığında, yaşam kariyerdir ya da kariyer yaşamın ta kendisidir. Bu nedenle, resmi bütünüyle kavramak daha doğru ve uygun görünmektedir (Chen, 2001).

Yaşamın her yönünün birbiri ile ilişkisi vardır. Örneğin aile rolü diğer yaşam rollerinden ayrı olarak ele alınamaz. Kariyer yaşamı gelişim alanları şu şekildedir: 1-Kendini tanıma ve kişilerarası ilişkiler (kendini anlama ve diğerlerinin eşsizliğinin farkına varma), 2-Yaşam rolleri, ortamları ve olayları (öğrenci, vatandaş, çalışan gibi roller; toplumda, evde, iş çevresi gibi ortamlarda; çalışma, evlilik ve emekliliğin başlaması gibi olaylar), 3-Yaşam kariyeri planlaması (karar verme ve planlama); 4Temel çalışmalar ve mesleki hazırlık (genellikle okul müfredatında bulunan çeşitli konularla ilgili bilgi ve beceriler) (Zunker, 2006, s.405). 
Super'in (1990) 'yaşam kariyeri gökkuşağı' belki de kariyer yaşamı konusunda en kalıcı ve en etkili kavramsal çalışma olmuştur. Bir kişi, farklı yaşam aşamalarıyla örtüşen çeşitli rolleri üstlenir. Bireylerin yaşam gelişim deneyimleri, kariyer gelişim tecrübelerini tamamlar ya da tam tersi olur (bkz. Savickas, 2005; Zunker, 2006). Super'in yaşam alanını bir gökkuşağı olarak tasvir etmesi, doğal dünyadan bir görüntüyü çağırmak için alışılmadık bir şey değildir. Bu gökkuşağı, kariyer seçimi ve gelişimi ile ilişkili olarak, yaşam boyu süren boylamsal boyutlar sunar. Yaşam kariyeri gökkuşağı yaşam rollerini şematik olarak ifade eder. Bireylerin gelişimsel süreçte oynadıkları çocuk, öğrenci, serbest zamanı çok olan, vatandaş, çalışan, eş, ev hanımı ve ebeveyn rolleri gibi. İnsanlar bu rolleri ev, okul, toplum ve iş yeri gibi ortamlarda sergilerler. Bu kavramsal model bazı ilginç gözlemlere sebep olmaktadır.1-İnsanlar birkaç rolü eş zamanlı olarak farklı ortamlarda sergilediklerinde birindeki başarı diğerini etkiler. 2-Çeşitli ortamlarda bütün roller birbirlerini etkiler (bkz. Sugarman, 2005, s.15-16; Redekop ve Luke, 2014; Roberts, 1977).

Konu ile ilgili bir diğer kuram ise, Holland (1985) tarafından geliştirilen özellik-faktör teorisidir. Holland bireysel ilgi ve yeteneklerin, bu ilgi ve yetenekleri tatmin eden bir meslekle eşleştirildiği zaman iş doyumunun, istikrarın ve başarının gerçekleştiğini varsaymaktadır. Holland, bir birey ile belirli bir meslek arasındaki uyuşma derecesini belirlemek için altı temel iş karakteri yönelimi ve altı adet mesleki sınıflandırma tanımlamıştır. Ayrıca Holland (1992), kariyer seçimlerini etkileyen faktörleri incelemiştir. Önemli olduğu saptanan etkenler şunlardır: aile; akran, öğretmen ve diğer yetişkin rol modelleri; okul, iş ve eğlence deneyimleri, sosyo-ekonomik durum ve etnik köken. Holland'ın teorisi kişilerin ve çevrelerin tipolojisine dayanan interaktif bir modeldir. Bireyler farklı kişilik türleri ile karakterize edilebilir ve bu insanların yaşadığı ve çalıştığı ortamlar aynı türlerle sınıflandırılabilir (bkz. Vinh, 2008; Hargett, 2011; Mahalik, 2001; Mumme, 1997).

Kariyer yaşam perspektifi, mesleki danışmanlıkta ele alınması gereken temel bir konudur (Zunker, 2006, s.11). Eğitim kurumlarında rehberlik ve danışmanlık hizmetleri kapsamında yürütülen kariyer danışmanlığı öğrencilerin yetenekleri ve ilgi alanları doğrultusunda doğru meslek seçimi ve ileriki yaşamında başarılı olmasında yönlendirici 
bir rolü üstlenmektedir (Bozgeyikli, Eroğlu ve Hamurcu, 2009; ÖzdemirYaylacı, 2007). Kariyer danışmanlığında danışmanlar kariyer yaşamını planlarken şu soruları değerlendirirler: Yaşamlarında iş ve mesleğin önemi. Farklı rollerdeki bağlılık ve değerler (örneğin, eğitim, çalışma, toplum, hizmet, ev ve aile). Danışanların bu rollerin her birinde diğerlerine göre harcadığı gerçek zaman ve tercihleri. Kariyer ve diğer mesleki olaraklar. İlgili roller doğrultusunda tutum, düşünce ve planlama derecesi. İş katılımı (örneğin, yaşamdaki ilgiler, aktif meslek katılımı, iş, benlik saygısı ve benlik kavramıyla ilişkili olarak performans) (Swanson ve D'Achiardi, 2005, s.360).

Danışmanların gençlerin kariyer yaşamını planlarken onlara sordukları sorular, ileride gencin kariyerini şekillendirmede belirleyici bir rol üstlenebileceği için son derece önem arz etmektedir. İşte bu noktada bu çalışmanın amacı, psikolojik danışmanların kariyer yaşamı planlamasına dair görüşlerini belirleyerek gençlerin kariyer yaşamı planlamasında hangi konular üzerinde durmaları gerektiğini vurgulamaktır. $\mathrm{Bu}$ amaç doğrultusunda aşağıdaki sorulara cevap aranacaktır:

1. Bireylerin kariyer yaşamını planlarken bu planlama sürecine hangi faktörler etki eder, anlatır mısınız?

2. Eş (evlilik) seçiminde önemli olan faktörler nelerdir, anlatır misiniz?

3. Meslek (iş) seçiminde önemli olan faktörler nelerdir, anlatır misiniz?

4. Kalacak yer (mesken) seçiminde önemli olan faktörler nelerdir, anlatir misiniz?

5. Serbest zamanı planlama ve geçirme ile ilgili önemli olan faktörler nelerdir, anlatır misiniz?

\section{Yöntem}

\section{Araştırmanın Modeli}

Çalışmada nitel araştırma tekniğinden yararlanılmıştır. Nitel araştırma olgu ve davranışların nasıl ve neden gerçekleştiğine odaklanır. Bu yöntemde araştırmacı verilere doğrudan kaynağından ulaşır, bağlam ve olguların derinlemesine anlaşılmasını sağlayacak detaylı betimlemeler 
yapılır (Büyüköztürk, Kılıç-Çakmak, Akgün, Karadeniz ve Demirel, 2008). Nitel araştırma özneldir, bireylerin algıları, duyguları, tecrübeleri, düşünceleri gibi öznel verileri ele alır. Olgu ve olayları söz konusu doğal ortamı içinde anlamaya ve açılamaya çalışır (Gürbüz ve Şahin, 2017, 406).

\section{Çalışma Grubu}

Çalışmada amaçlı örnekleme yönteminden yararlanılmıştır. Amaçlı çalışma grupları genel olarak nitel araştırmalarda kullanılabilir. Nitel araştırmalarda elde edilen bulguların evrene genellemesi söz konusu olmayabilir. Bu durumda örneklemin evreni temsil etme gibi bir zorunluluğu da yoktur (Sönmez ve Alacapınar, 2017, 174). Çalışma grubuna psikolojik danışman seçim kriteri bu araştırmaya gönüllü olarak katılmak isteyen psikolojik danışmanlar üzerinde yapılmasıdır. Araştırma Necmettin Erbakan Üniversitesinde yüksek lisans yapmakta olan kariyer danışmanlığ 1 dersini almış psikolojik danışmanlar üzerinde yapılmıştır. Araştırmanın çalışma grubu 34 psikolojik danışmandan oluşmaktadır. Bu psikolojik danışmanların 20'si (\%58.87) kadın, 14'ü (\%41.13) erkektir. Psikolojik danışman olarak görev yapma yılına göre 1-9 yıl arasında dağılım göstermektedirler. 1-3 yıl arasında görev yapanlar 21 kişi (\%61.77), 4-6 yıl arasında görev yapanlar 9 kişi (\%26.47), 7-9 yıl arasında görev yapanlar ise 4 kişi (\%11.76)'dir.

\section{Yarı Yapılandırılmış Görüşme Tekniği}

Çalışmada veri toplama yöntemi olarak yarı yapılandırılmış görüşme tekniğinden yararlanılmış ve ilgili literatür göz önünde bulundurulmuştur. Özellikle literatür olarak gençlerin kariyer yaşamlarının nasıl planlanacağ1 üzerinde durulmuştur. Gençlik tüm hayat süreci içinde önemli bir yere sahip olan kendini kabul ettirme, yönelme ve karar verme dönemidir. $\mathrm{Bu}$ süreç ileriki yaşam için en önemli ve merkezi kararların alındığı süreçtir (APK, 2004, s.22). Bundan yola çıkarak gençlerin kariyer yaşamını planlama noktasında psikolojik danışmanların görüşlerini tespit etmek için sorulardan oluşan yarı yapılandırılmış görüşme formu geliştirilmiştir. Kullanılan görüşme formunun 
geçerliliğini temin etmek için Necmettin Erbakan Üniversitesinde görev yapmakta olan altı öğretim üyesinin görüşlerinden faydalanılmış ve öğretim üyelerinin görüşleri dikkate alınarak yarı yapılandırılmış görüşme formu oluşturulmuştur. Pilot uygulamalar yapıldıktan sonra alınan tüm bu sonuçlara göre görüşme formları uygulama için uygun hâle getirilmiştir.

Nitel araştırmalarda kullanılan görüşme tekniği, üzerinde araştırma yapılan kişilerin bakış açılarını ortaya koyma, dünyayı onların gözleriyle görme amacıyla kullanılmaktadır. Bu tekniğin belirleyici özelliği görüşülen kişilerin bakış açlarını ortaya çıkarmaktır. $\mathrm{Bu}$ nedenle görüşülenlerin anlam dünyalarını duygu ve düşüncelerini anlamak daha derinlemesine bilgi edinmek esastır (Kuş, 2006). Yapılan uygulamalar iletişim ve kayıt biçimi bakımından değerlendirildiğinde katılımcılarla yazılı görüşme yapılmış olup yazılı görüşme, araştırmanın konusuna amacına uygun olarak görüşülen kişiyle yüz yüze ya da bir iletişim aracı kullanarak yapılır (Aypay vd., 2014, 152).

\section{Verilerin Toplanması}

Araştırmaya katılan kişilerle yapılan görüşmeler katılımcıların gönüllülüklerine riayet edilerek yapılmıştır. Çalışmanın amacının ve nasıl gerçekleştirileceğinin net bir şekilde belirtildiği bir açıklama hazırlanmış ve görüşme esnasında sunulmuştur. Görüşmecilerinin kimliklerinin gizli kalacağı ile ilgili teminat verilmiştir. Veri toplamak amacıyla yazılı görüşme formlarından yararlanılmıştır. Katılımcılar ile yapılan görüşmeler yaklaşık 35-40 dakika sürmüştür.

\section{Verilerin Analizi ve Yorumlanması}

Toplanan veriler, içerik analizi tekniği ile analiz edilmiştir. İçerik analizi bir konu hakkında betimleyici bilgi sağlamak, betimleyici bilgilerin düzenlenmesine ve anlaşılır hale gelmesine yardımcı olarak temaları ortaya çıkarmak ya da ilgili problemle baş etmeye yönelik bilgi toplamak için yapılır (Büyüköztürk, Kılıç-Çakmak, Akgün, Karadeniz ve Demirel, 2008). İçerik analizi herhangi bir yazılı metnin ya da belgenin içeriğinin incelenmesi ve sayısal olarak ortaya konulmasında kullanılan 
bir analiz çeşididir (Ekiz, 2017, 77).

Yarı yapılandırılmış görüşmede görüşme formunun yarısı yapılandırılmış yarısı yapılandırılmamış bir biçimde hazırlanır. Görüşmecinin görüşme esnasında vereceği tepkilere dayalı olarak açık uçlu görüşme formu esnek bir biçimde hazırlanmış olur (Aypay vd., 2014, 151). Katılımcılardan elde edilen veriler yarı yapılandırılmış formlara yazılı olarak alınmıştır. Her bir veri formuna numara verilmiştir.

Nitel veri analizinde ilk aşama betimleme aşamasıdır. Burada araştırma konusu ile ilgili birey, davranış, olay veya olgularla ilgili özellikler ortaya çıkarılır. Daha sonra betimleme ile tanımlanmış olan veriler belirli kategoriler halinde sınıflandırılır. Araştırmacı kategoriler içerisinde çeşitli temalar geliştirir ve bu temaları karşılaştırarak farklılıkları inceler. Verilerden elde edilen kategori ve temalar arasındaki örüntülerin oluşturulması ile incelenen olay veya olgu açıklığa kavuşmuş olur (Akt. Gürbüz ve Şahin, 2017).

Kodlama kategorileri belirlenirken araştırmacı araştıracağı konunun boyutlarını mümkün olduğunca net bir şekilde tanımladıktan sonra araştırma ile ilgili olan uygun kategorileri belirler. Kategoriler başka araştırmacıların da aynı materyali incelediğinde aynı sonuçlara ulaşmasını sağlayacak kadar açık olmalıdır (Büyüköztürk, Kılıç-Çakmak, Akgün, Karadeniz ve Demirel, 2008). Kodlama ve kodlar arasındaki ilişkileri analiz süreci geleneksel olarak nitel araştırmacıların elle ve basit metotlar ile yapabilecekleri bir süreçtir. Ancak 1980'lerden günümüze bu sürece yardımcı olmak amaciyla bir takım bilgisayar programları geliştirilmiştir (Güler, Halıcıoğlu ve Taşğın, 2015). Kodlama yapılırken araştırmanın amacı ve görüşme soruları dikkate alınmıştır. Bu amaç doğrultusunda Nvivo7 bilgisayar destekli nitel veri analiz programından faydalanılmıştır.

$\mathrm{Bu}$ araştırma için ilgili literatür de dikkate alınarak elde edilen görüşler sonucunda kariyer yaşamına etki eden faktörler, eş seçiminde önemli olan faktörler, meslek seçiminde önemli olan faktörler, kalacak yer seçiminde önemli olan faktörler, serbest zamanı planlama ve geçirme temaları belirlenmiştir. Bu temalar alt kategorilere ayrılmıştır. Her bir kategori ile ilgili olarak örnek psikolojik danışman görüşlerine yer verilmiştir. 


\section{Bulgular}

Bireylerin kariyer yaşamının nasıl planlanacağı ile ilgili psikolojik danışmanların görüşlerine göre 5 tema (kariyer yaşamına etki eden faktörler, eş seçiminde önemli olan faktörler, meslek seçiminde önemli olan faktörler, kalacak yer seçiminde önemli olan faktörler, serbest zamanı planlama ve geçirme) belirlenmiştir. Bu 5 tema daha sonra kategorileştirilmiştir. Tablo 1'de temalar, kategoriler, psikolojik danışmanların görüşleri ve sayısı yer almaktadır.

\section{1-Kariyer Yaşamına Etki Eden Faktörler Teması}

Kariyer yaşamına etki eden faktörler teması 6 kategoriden oluşmaktadır. $\mathrm{Bu}$ kategoriler yaşam yeri (mesken seçimi, çevre), iş ve meslek seçimi, psikolojik ihtiyaçlar, mesleğin sağladığı imkânlar (eğitim durumu, maddiyat, mesleğin getirileri), eş seçimi, serbest zaman faaliyetleri olarak sıralanmaktadır. Araştırmaya katılan 34 psikolojik danışmandan 25'i "yaşam yeri", 18'i "iş ve meslek seçimi", 18'i "psikolojik ihtiyaçlar", 15'i "mesleğin sağladığı imkânlar", 16'sı eş seçimi, 12'si serbest zaman faaliyetleri kategorilerinde görüş belirtmişlerdir. Bu kategoriler ile ilgili örnek psikolojik danışman görüşlerine Tablo 1'de yer verilmektedir.

Tablo 1. Psikolojik Danışmanların Kariyer yaşamına etki eden faktörler temasına dair Görüşleri

\begin{tabular}{|c|c|c|c|}
\hline 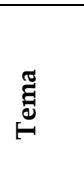 & Kategoriler & $\begin{array}{c}\text { Kategorilere } \\
\text { Katılan } \\
\text { Psikolojik } \\
\text { Danışman } \\
\text { Sayısı }\end{array}$ & Psikolojik Danışman Görüşlerinden Örnekler \\
\hline \multirow{3}{*}{ 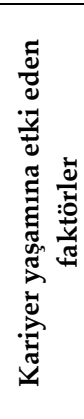 } & $\begin{array}{l}\text { Yaşam yeri } \\
\text { (mesken } \\
\text { seçimi, çevre) }\end{array}$ & 25 & $\begin{array}{l}\text { "Planlamadaki etkili olacak faktörlerin biri de mes- } \\
\text { ken seçimi olurdu. İnsanin günlük işlerden bunalan } \\
\text { ruh dengesi, iyi seçilmiş bir meskende yeni bir güne } \\
\text { taze enerjiyle başlaması gerekir." (P5'in görüşü) }\end{array}$ \\
\hline & $\begin{array}{l}\text { İş ve meslek } \\
\text { seçimi }\end{array}$ & 18 & $\begin{array}{l}\text { "En öncelikli olarak iş seçimidir. İş olarak kişinin } \\
\text { istediğini, gelecekte nerede olmak istediğini bilmesi } \\
\text { gerekir" (P10'un görüşü) }\end{array}$ \\
\hline & $\begin{array}{l}\text { Psikolojik } \\
\text { ihtiyaçlar }\end{array}$ & 18 & $\begin{array}{l}\text { "Öncelikli olarak hayatı bir bütün olarak algilayarak } \\
\text { bu planlamayı yapmak gerekir. Yani evrensel ve } \\
\text { bireysel değerleri hissetme ve uygulamaya geçirme } \\
\text { şansına sahip olmak, bunları yaparken iyi ve mutlu }\end{array}$ \\
\hline
\end{tabular}




\begin{tabular}{|c|c|c|}
\hline & & $\begin{array}{l}\text { hissetmek, üretirken hem bedenen hem de ruhen } \\
\text { doyuma ulaşmak, değişimin dinamikleri altında } \\
\text { ezilmemek, bilakis değişimi yaratmak. Tüm bunlar } \\
\text { için gerekli olan asgari psikolojik, fiziksel ve } \\
\text { ekonomik faktörler ve bunların uyumları noktasın- } \\
\text { daki Altın Orta'yı bulmak" (P3'ün görüşü) }\end{array}$ \\
\hline $\begin{array}{c}\text { Mesleğin } \\
\text { Sağladiğı } \\
\text { imkânlar } \\
\text { (eğitim duru- } \\
\text { mu, maddiyat, } \\
\text { mesleğin } \\
\text { getirileri), }\end{array}$ & 15 & $\begin{array}{l}\text { "Yaşam kariyerini planlarken ilk önce iş için iyi bir } \\
\text { eğitim almaya gayret gösterilmeli. Çünkü diğer } \\
\text { kısımlardan önce iş önemlidir. Eğer genç yeterli } \\
\text { eğitim, yetenek, ilgi elde edemezse iş konusunda } \\
\text { sıkıntı çeker". (P20'nin görüşü) }\end{array}$ \\
\hline Eş seçimi & 16 & $\begin{array}{l}\text { "Kariyer yaşamında bireye destekçi ve kendi bakış } \\
\text { açısıyla bakabilen bir kişiye ihtiyaç vardır. Bu kişi en } \\
\text { yakınımız olan eşimizdir." (P18'in görüşü) }\end{array}$ \\
\hline $\begin{array}{l}\text { Serbest zaman } \\
\text { faaliyetleri }\end{array}$ & 12 & $\begin{array}{l}\text { "Aile yaşamına ve serbest zaman faaliyetlerine süre } \\
\text { arttırmaya müsaade eden düzenli ya da esnek mesai } \\
\text { saati olan, hafta sonu tatili olan bir iş olması." } \\
\text { (P32'nin görüşü) }\end{array}$ \\
\hline
\end{tabular}

\section{2-Eş Seçiminde Önemli olan Faktörler Teması}

Eş seçiminde önemli olan faktörler teması 4 kategoriden oluşmaktadır. Bu kategoriler beklentilere uygunluk, kişilik özellikleri, benzerlik, bütünleşme olarak sıralanmaktadır. Araştırmaya katılan 34 psikolojik danı̧̧mandan 30'u "beklentilere uygunluk", 21'i" kişilik özellikleri, 19'u "benzerlik", 3'u "bütünleşme" kategorilerinde görüş belirtmişlerdir. Bu kategoriler ile ilgili örnek psikolojik danışman görüşlerine Tablo 2'de yer verilmektedir.

Tablo 2. Psikolojik Danışmanların Eş seçiminde önemli olan faktörler temasına dair Görüşleri...

\begin{tabular}{|c|c|c|c|}
\hline 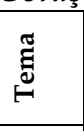 & Kategoriler & $\begin{array}{c}\text { Psikolojik } \\
\text { Danışman } \\
\text { Sayısı } \\
\end{array}$ & Psikolojik Danışman Görüşlerinden Örnekler \\
\hline 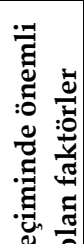 & $\begin{array}{l}\text { Beklentilere } \\
\text { uygunluk }\end{array}$ & 30 & $\begin{array}{l}\text { "Eş seçiminde çiftlerin beklentileri tutarlı olmalı, } \\
\text { kişinin beklentileriyle uygun olacak, uygun } \\
\text { olmayanlar tolere edilebilir olacak, yaşam şekli, } \\
\text { yaşamdan beklentileri iki eşin birbirine uygun } \\
\text { olmalı. Biri yaşama karşı sımsıkı sarılmış, diğeri } \\
\text { boş vermiş olmamalı." (P11'in görüşü) }\end{array}$ \\
\hline 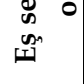 & $\begin{array}{c}\text { Kişilik } \\
\text { özellikleri }\end{array}$ & 21 & $\begin{array}{l}\text { "Bunun dışında kişinin nasıl bir mizaç ve karak- } \\
\text { terde olduğu da önemli bir faktördür. Bu da bir }\end{array}$ \\
\hline
\end{tabular}




\begin{tabular}{|c|c|c|}
\hline & & $\begin{array}{l}\text { nevi psikolojik ihtiyaçlara tekabül etmektir." } \\
\text { (P2'nin görüşü) }\end{array}$ \\
\hline Benzerlik & 19 & $\begin{array}{l}\text { "Eş seçimi yaparken benzer bütünlük ilkesi } \\
\text { geçerlidir. Seçilen eşte ya benzer özellik aranır ya } \\
\text { da özelliklerin birbirini tamamlaması. Bu veriler } \\
\text { ele alındıktan sonra tercih yapılır." (P24'ün } \\
\text { görüşü) }\end{array}$ \\
\hline Bütünleşme & 3 & $\begin{array}{l}\text { "Aile bütünlüğü içerisinde kişinin bireyselliğini } \\
\text { koruyabilecek, karşıllklı bilgi alışverişinde } \\
\text { bulunabileceği güzel birtakım oluşturabileceği } \\
\text { birisini seçmesi gerekir." (P12'nin görüşü) }\end{array}$ \\
\hline
\end{tabular}

\section{3-Meslek Seçiminde Önemli Olan Faktörler Teması}

Meslek seçiminde önemli olan faktörler teması 7 kategoriden oluşmaktadır. Bu kategoriler değerler, psikolojik ihtiyaçlara uygunluk, yeteneklere uygunluk, ilgi, serbest zaman faaliyetleri, eğitim durumu, kişilik özellikleri olarak sıralanmaktadır. Araştırmaya katılan 34 psikolojik danışmandan 27'si "değerler", 26'sı "psikolojik ihtiyaçlara uygunluk", 19'u "yeteneklere uygunluk", 16'si "ilgi", 8'i "serbest zaman faaliyetleri", 4'ü "eğitim durumu", 3’ü "kişilik özellikleri" kategorilerinde görüş belirtmişlerdir. Bu kategoriler ile ilgili örnek psikolojik danışman görüşlerine Tablo 3'de yer verilmektedir.

Tablo 3. Psikolojik Danışmanların Meslek seçiminde önemli faktörler temasına dair Görüssleri...

\begin{tabular}{|c|c|c|c|}
\hline 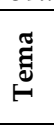 & Kategoriler & $\begin{array}{l}\text { Psikolojik } \\
\text { Danışman } \\
\text { Sayısı }\end{array}$ & Psikolojik Danışman Görüşlerinden Örnekler \\
\hline \multirow{4}{*}{ 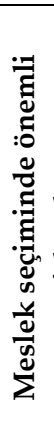 } & Değerler & 27 & $\begin{array}{l}\text { "Yapılacak iş rahat mi, psikolojik olarak yıpratan } \\
\text { bir iş mi, çalışma şartları ve çalışılan ortamda } \\
\text { önemlidir." (P9'un görüşü) }\end{array}$ \\
\hline & $\begin{array}{l}\text { Psikolojik } \\
\text { ihtiyaçlara } \\
\text { uygunluk }\end{array}$ & 26 & $\begin{array}{l}\text { "Tatili ve kişinin kendine ayıracağı zamanlar1 } \\
\text { seçmesi konusunda daha özgür olabileceği bir } \\
\text { meslek sahibi olması önemlidir" (P33'ün görüşü) }\end{array}$ \\
\hline & $\begin{array}{c}\text { Yeteneklere } \\
\text { uygunluk }\end{array}$ & 19 & $\begin{array}{l}\text { "Kişi meslek seçerken hem ilgi ve yeteneklerini göz } \\
\text { önünde bulundurmalı, hem de herhangi bir mes- } \\
\text { leği seçmesi takdirinde eline geçecek olanları } \\
\text { değerlendirmesi gerekir." (P15'in görüşü) }\end{array}$ \\
\hline & İlgi & 16 & "Seçeceği iş aldı̆̆ eğitimle örtüşmüyor mu, ilgi ve \\
\hline
\end{tabular}




\begin{tabular}{|c|c|c|}
\hline & & $\begin{array}{l}\text { ihtiyaçlarının ne kadarını karşılıyor, çalışma saat- } \\
\text { leri, koşulları, maaş durumu, zamanla ve gelişmel- } \\
\text { erle geçerliliğini yitirip yitirmediği, sosyal imkânlar } \\
\text { önemlidir." (P4'ün görüşü) }\end{array}$ \\
\hline $\begin{array}{l}\text { Serbest za- } \\
\text { man faaliyeti }\end{array}$ & 8 & $\begin{array}{l}\text { "Bireyin kendine zaman ayırmasına fırsat vermesi, } \\
\text { tatilinin uygun zamanlarda olması." (P10'un } \\
\text { görüşü) }\end{array}$ \\
\hline $\begin{array}{l}\text { Eğitim du- } \\
\text { rumu }\end{array}$ & 4 & $\begin{array}{l}\text { "Bir meslek seçilirken dikkat edilmesi gereken bir } \\
\text { diğer konuda, mesleğin hangi alanlarda geçerli } \\
\text { olduğunu, eğitim süreci bittikten sonra nerelerde } \\
\text { çalışlabileceğini gayet iyi araştırmak gereklidir." } \\
\text { (P19'un görüşü) }\end{array}$ \\
\hline $\begin{array}{l}\text { Kişilik özel- } \\
\text { likleri }\end{array}$ & 3 & $\begin{array}{l}\text { "Seçilecek mesleğin kişilik özelliklerine, ilgi ve } \\
\text { yeteneklere, becerilere uygun olması gerekir." } \\
\text { (P21'in görüşü) }\end{array}$ \\
\hline
\end{tabular}

\section{4-Kalacak Yer Seçiminde Önemli Olan Faktörler Teması}

Kalacak yer seçiminde önemli olan faktörler teması 3 kategoriden oluşmaktadır. Bu kategoriler semt özellikleri, fiziki koşullar, maliyet olarak sıralanmaktadır. Araştırmaya katılan 34 psikolojik danışmandan 27'si "semt özellikleri", 15'i “fiziki koşullar", 7'si "maliyet" kategorilerinde görüş belirtmişlerdir. Bu kategoriler ile ilgili örnek psikolojik danışman görüşlerine Tablo 4'de yer verilmektedir.

Tablo 4. Psikolojik Danışmanların Kalacak yer seçimi temasına dair Görüşleri...

\begin{tabular}{|c|c|c|c|}
\hline$\underset{\mathfrak{g}}{\stackrel{\mathfrak{g}}{E}}$ & Kategoriler & $\begin{array}{c}\text { Psikolojik } \\
\text { Danışman } \\
\text { Sayısı } \\
\end{array}$ & Psikolojik Danışman Görüşlerinden Örnekler \\
\hline \multirow{2}{*}{ 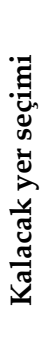 } & $\begin{array}{l}\text { Semt özel- } \\
\text { likleri }\end{array}$ & 27 & $\begin{array}{l}\text { "Ferah, güvenli, derli-toplu bir evde yaşamak ya } \\
\text { da sakin, sessiz bir yerleşim merkezinde yaşamak } \\
\text { insanların yoğun bir temponun etrafında ra- } \\
\text { hatlamasına neden olacaktır."(P30'un görüşü) }\end{array}$ \\
\hline & $\begin{array}{l}\text { Fiziki } \\
\text { koşullar }\end{array}$ & 15 & $\begin{array}{l}\text { "Kalacak yer seçiminde önemli faktörler arasında } \\
\text { evin konumu önemlidir. Sıkışık, dar çalışma } \\
\text { odasının olmadı̆̆ı, oldukça gürültülü, apartman } \\
\text { dairesi yerine, çalışma odasının olduğu, } \\
\text { gürültüden uzak, doğa ile baş başa, bahçesinde }\end{array}$ \\
\hline
\end{tabular}




\begin{tabular}{|l|l|l|l|}
\hline & & \multicolumn{2}{|l|}{ çeşitli çiçeklerin olduğu bir mesken olması önem- } \\
& & lidir."(P6'nın görüşü) \\
\cline { 2 - 4 } & & $\begin{array}{l}\text { “Kalacak yer seçiminde en önemli faktör } \\
\text { Maliyet }\end{array}$ & $\begin{array}{l}\text { ülkemizde maddi imkânlardır. İnsan maddi } \\
\text { imkânları çerçevesinde kalacağ1 yeri seçmekte- } \\
\text { dir." (P13'ün görüşü) }\end{array}$ \\
\hline
\end{tabular}

\section{5-Serbest Zamanı Planlama ve Geçirme Teması}

Serbest zamanı planlama ve geçirme teması 6 kategoriden oluşmaktadır. $\mathrm{Bu}$ kategoriler aileye, kendine ve çevreye zaman ayırma; ilgi ve yetenekler; işin özellikleri, maddi koşullar ve zaman; kişisel gelişime katkısı; sosyal faaliyetler ve imkânlar; verimlilik olarak sıralanmaktadır. Araştırmaya katılan 34 psikolojik danışmandan 21'i "aileye, kendine ve çevreye zaman ayırma", 21'i "ilgi ve yetenekler", 19'u "işim özellikleri maddi koşullar ve zaman", 10'u "kişisel gelişime katkısı", 2'si "sosyal faaliyetler ve imkânlar", 2'si "verimlilik" kategorilerinde görüş belirtmişlerdir. Bu kategoriler ile ilgili örnek psikolojik danışman görüşlerine Tablo 5 'de yer verilmektedir.

Tablo 5. Psikolojik Danışmanların Serbest zamanı planlama ve geçirme temasına dair Görüşleri...

\begin{tabular}{|c|c|c|c|}
\hline$\stackrel{\overparen{\Xi}}{\stackrel{\Xi}{\oplus}}$ & Kategoriler & $\begin{array}{c}\text { Psikolojik } \\
\text { Danışman } \\
\text { Sayısı } \\
\end{array}$ & Psikolojik Danışman Görüşlerinden Örnekler \\
\hline \multirow{4}{*}{ 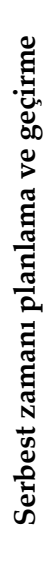 } & $\begin{array}{l}\text { Aileye, } \\
\text { kendine ve } \\
\text { çevreye za- } \\
\text { man ayırma }\end{array}$ & 21 & $\begin{array}{l}\text { "Serbest zaman etkinliklerini aileyle geçirmek } \\
\text { çok önemlidir. Çünkü kariyer yaşamında aileye } \\
\text { zaman ayırmama durumu olamaz."(P22'nin } \\
\text { görüşü) }\end{array}$ \\
\hline & $\begin{array}{c}\text { İlgi ve } \\
\text { yetenekler }\end{array}$ & 21 & $\begin{array}{l}\text { "Bireyin ilgi duyduğu alanlar onu mutlu eden } \\
\text { doyum sağlayan etkinlikler nelerdir, bu etkin- } \\
\text { liklerin mahiyeti nelerdir, ne kadar zaman alıyor- } \\
\text { lar sorularına cevap aranır."(P25'in görüşü) }\end{array}$ \\
\hline & $\begin{array}{l}\text { İşin özel- } \\
\text { likleri, maddi } \\
\text { koşullar ve } \\
\text { zaman } \\
\end{array}$ & 19 & $\begin{array}{l}\text { "Boş zamanın geçirebileceği dönemde yaşamı iyi } \\
\text { bir standartta (maddi olarak) geçirmek önem- } \\
\text { lidir. Birey hayatının geriye kalan kısmında bu } \\
\text { konuda kaygı yaşamamalıdır." (P28'in görüşü) }\end{array}$ \\
\hline & $\begin{array}{c}\text { Kişisel } \\
\text { gelişime }\end{array}$ & 10 & $\begin{array}{l}\text { "Serbest zaman boş boş oturma, TV seyretmek } \\
\text { demek değildir. Doğal olarak bunları da yapmak }\end{array}$ \\
\hline
\end{tabular}




\begin{tabular}{|c|c|c|}
\hline katkısı & & $\begin{array}{l}\text { gerekir. Kişisel gelişimle ilgili kitaplar okumak, } \\
\text { sinema, tiyatro, konsere gitmek, piknik yapma, } \\
\text { tarihi yerleri gezme, arkadaş toplantıları ve ev } \\
\text { gezmeleri gibi." (P34'ün görüşü) }\end{array}$ \\
\hline $\begin{array}{l}\text { Sosyal faali- } \\
\text { yetler ve } \\
\text { imkânlar }\end{array}$ & 2 & $\begin{array}{l}\text { "Sağlık faktörleri ve imkanlar dahilinde mümkün } \\
\text { olduğunca çok yer gezmek ve görmek sosyal } \\
\text { faaliyetlerin bir bölümüdür." (P1'in görüşü) }\end{array}$ \\
\hline Verimlilik & 2 & $\begin{array}{l}\text { "Serbest zamanı planlama veya geçirme ile ilgili } \\
\text { önemli olan faktör verimliliktir. Serbest zamanı } \\
\text { geçirmede zamanın azlığı veya çokluğundan } \\
\text { ziyade onun verimli olması önemlidir. Verimsiz } \\
\text { geçirilmiş bir serbest zamanın planlanıp plan- } \\
\text { lanmaması arasında fark yoktur. } \\
\text { (P7'nin görüşü) }\end{array}$ \\
\hline
\end{tabular}

\section{Tartışma}

Kariyer danışmanlığının en büyük zorluklarından biri danışanların seçimlerini belirlemektir (Osipow, 1999). Çoğu kariyer seçimi, bireylerin önemli kişilerle olan ilişkileri, toplumsal çevreleri ve benzeri gibi kişinin çalışma ortamıyla doğrudan ilgisi olmayan yönleri de içeren çeşitli yaşam alanlarını etkiler (Gati ve Tal, 2008, s. 159). Kariyer seçiminde önemli olan bu yaşam alanlarından birinin de yaşam yeri seçimi olması muhtemeldir. Çalışmaya katılan psikolojik danışmanların ortak görüşüde yaşanılan yerin kariyer yaşamında önemli olduğu yönündedir.

Kariyer yaşamında pek çok insan meslek seçiminin zor olduğunu düşünür. Kararın nasıl alınacağı ve mesleki bilginin nereden elde edileceği de bu süreci zorlaştıran diğer unsurlardır (Saka, Gati ve Kelly, 2008). Zor olmasına rağmen meslek seçimi kariyer yaşamı için olmazsa olmazlardandır denilebilir. Araştırmaya katılan psikolojik danışmanların çoğunluğu da meslek seçiminin önemli olduğu yönünde görüş belirtmişlerdir.

Bozgeyikli ve Toprak (2013) gençlerin eş seçiminde en önem verdikleri kriter olarak kişiliği gördükleri sonucuna ulaşmışlardır. Tüzümen ve Özdağoğlu (2007) da karakterin eş seçiminde etkili olduğunu belirtmişlerdir. Bacanlı (2001)'nın eş tercihleri ile ilgili yaptığı çalışmada güvenilir kişilik özelliğinin bir grup için en önemli tercih sebebi olduğu ortaya 
konulmuştur. Kişilik özelliklerinin eş seçiminde önemini vurgulayan başka çalışmalar da mevcuttur (Botwin, Buss ve Shackelford,1997; Buss ve Barnes, 1986). Eş seçiminde değerlerin ve karşı cinsten beklentilerin önemini vurgulayan çalışmalar da mevcuttur (Buss, Shackelford, Kirkpatrick ve Larsen, 2001; Gangestad, Haselton ve Buss, 2006; GirginBüyükbayraktar, Özteke ve Kesici, 2015; Özteke, Girgin-Büyükbayraktar ve Kesici, 2015; Kurzban ve Weeden, 2005; Yıldırım, 2007). Bu bulgulara paralel olarak araştırmaya katılan psikolojik danışmanlardan çoğunluğu kişilik özelliklerinin ve beklentilere uygunluğun eş seçiminde önemli faktörler arasında yer aldığını belirtmişlerdir.

Kariyer planlama döneminde gençler kendileri ile meslekler arasında bir yakınlık kurmaya çalışırlar. Bu noktada meslek fiziksel, kişisel, ahlaki, sosyolojik ve ideolojik özelliklerden etkilenir (Guichard ve Dumora, 2008, s. 190). Olumlu ya da olumsuz değerler işe atfedilebilir (Arulmani, 2014, s.90). Savickas (2005, s.47) mesleki kişiliği bireylerin kariyer ile ilgili yetenekleri, ihtiyaçları, değerleri ve ilgileri olarak tanımlamıştır. Ayrıca Savickas, bireylerin kariyer sürecini oluşturmak için yorumlayı ı ve kişiler arası süreçler kullandıklarını ve bunların meslek seçimindeki davranış ve tutumları yönlendirmede etkili olduğunu belirtir. Bireysel farklılıklar, başa çıma stratejileri ve psikodinamik motivasyonda bu süreçte yer alır. Bunun yanında Savickas bireysel ihtiyaçlara da odaklanır (Savickas, 2001). Mesleki değerler seçim sürecinde önemli bir husustur (Bozgeyikli, Bacanlı ve Doğan, 2009; Kesici, 2007b; Kesici 2008a; Kesici, 2008b). Ayrica Hartung, Porfeli, Vondracek (2005)'da ilgi ve değerlerin mesleki karar sürecinde etkili olduğunu belirtmişlerdir. $\quad \mathrm{Bu}$ görüşlerle örtüşür şekilde araştırmaya katılan psikolojik danışmanlardan çoğunluğu değerler ve psikolojik ihtiyaçlara uygunluğun meslek seçiminde önemli olan faktörler arasında olduğunu belirtmişlerdir.

Bireyselci toplumlarda konut bir sosyal statü göstergesidir (Edgü, 2003). Bu bakış açısıyla yaklaşıldığında kalacak yer, kalacak yerin bulunduğu semt ve kalacak yerin fiziki koşullarının kariyer yaşamını planlamada etkili faktörler arasında yer aldığı söylenilebilir. Bu doğrultuda araştırmaya katılan psikolojik danışmanlardan çoğunluğu semt özellikleri ve fiziki koşulların kalacak yer seçiminde önemli olan faktörler arasında yer aldığını belirtmişlerdir. 
McMahon ve Patton (2002)'nin kariyer danışmanlarının kariyer sürecini değerlendirmeleri ile ilgili önerdikleri rehberde, işte iyi sosyal ilişkilere sahip olma ve serbest zaman önemli unsurlardandır. İş ile serbest zaman etkinlikleri arasında psikolojik sağlık açısından bir ilişki bulunmuştur (Ryan, Bernstein ve Brown, 2010). Keisci(2007a), gençlerin kariyer yaşamını belirlemede serbest zamanın planlamasının önemini vurgulamıştır.

Bu bulgulara parallel olarak araştırmaya katılan psikolojik danışmanlardan çoğunluğu ilgi-yetenekler ve işin özellikleri- maddi koşullarzamanın, serbest zamanı planlama ve geçirme konusunda önemli faktörlerden olduğunu belirtmişlerdir.

\section{Sonuç}

1- Araştırmaya katılan psikolojik danışmanlardan çoğunluğu yaşam yeri ve iş-meslek seçiminin kariyer yaşamına etki eden önemli faktörlerden olduğunu belirtmişlerdir.

2- Araştırmaya katılan psikolojik danışmanlardan çoğunluğu beklentilere uygunluk ve kişilik özelliklerinin eş seçiminde önemli faktörler arasında yer aldığını belirtmişlerdir.

3- Araştırmaya katılan psikolojik danışmanlardan çoğunluğu değerler ve psikolojik ihtiyaçlara uygunluğun meslek seçiminde önemli olan faktörler arasında olduğunu belirtmişlerdir.

4- Araştırmaya katılan psikolojik danışmanlardan çoğunluğu semt özellikleri ve fiziki koşulların kalacak yer seçiminde önemli olan faktörler arasında yer aldığını belirtmişlerdir.

5- Araştırmaya katılan psikolojik danışmanlardan çoğunluğu ilgiyetenekler ve işin özellikleri-maddi koşullar-zamanın serbest zamanı planlama ve geçirme konusunda önemli faktörlerden olduğunu belirtmişlerdir. 


\section{Kaynakça}

Arulmani, G. (2014). The cultural preparation process model and career development. (Edt. Gideon Arulmani, Anuradha J. Bakshi, Frederick T.L. Leong, A.G. Watts). In Handbook of Career Development International Perspectives. Springer Science-Business Media.

Bacanl, H. (2001). Eş tercihleri. Türk Psikolojik Danışma ve Rehberlik Dergisi, 2(15), 7-16.

Bandura, A., Barbaranelli, C., Caprara, G. V. ve Pastorelli, C. (2001). Selfefficacy beliefs as shapers of children's aspirations and career trajectories. Child Development, 72(1), 187-206.

Botwin, M. D., Buss, D. M. ve Shackelford, T. K. (1997). Personality and mate preferences: Five factors in mate selection and marital satisfaction. Joumal of Personality, 65, 1.

Bozgeyikli, H., Bacanlı, F. ve Doğan, H. (2009). İlköğretim sekizinci sınıf öğrencilerinin mesleki karar verme yetkinliklerinin yordayıcılarının incelenmesi. Selçuk Üniversitesi Sosyal Bilimler Enstitüsü Dergisi, 21, 125-136.

Bozgeyikli, H., Eroğlu, S. E. ve Hamurcu, H. (2009). Career decision making self-efficacy, career maturity and socioeconomic status with Turkish youth. Georgian Electronic Scientific Journal: Education Science and Psychology, 1(14), 15-24.

Bozgeyikli, H. ve Toprak, E. (2013). Üniversiteli gençlerin eş seçim kriterlerinin sıralama yargılarıyla ölçeklenmesi. Gençlik Araştırmaları Dergisi, 1, (1), 69-84.

Brott, P. E, ve Myers, J. E. (2002). Development of professional school counselor identity a grounded theory. (Edt. S. B., Merriam et al.). In Qualitative research in practice examples for discussion and analysis San Francisco: Jossey-Bass A Wiley Company, pp. 145-160.

Buss, D. M. ve Barnes, M. (1986). Preferences in human mate selection. Journal of Personality and Social Psychology, 50(3), 559-570.

Buss, D. M., Shackelford, T. K., Kirkpatrick, L. A. ve Larsen, R. J. (2001). A half century of mate preferences: the cultural evolution of values. Journal of Marriage and Family, 63, 491-503. 
Büyüköztürk, Ş., Kılıç-Çakmak, E., Akgün, Ö. E., Karadeniz, Ş. ve Demirel, F. (2008). Bilimsel araştırma yöntemleri (2.Baskı). Ankara: Pegem Akademi.

Chen, C. P. (2001). Career counselling as life career integration. Journal of Vocational Education \& Training, 53(4), 523-542.

Coolican, H. (1992). Research methods and statistics in psychology. London: Hodder \& Stougtton.

Dikaiou, M. (2000). Concepts, theories and Practices. (Edt. J. Gibson-Cline) In Youth and Coping in Twelve Nations. London: Routledge.

Erikson, E. H. (1977). Childhood and society. London: Paladin Grafton Books.

Edgü, E. (2003). Konut tercihlerinin, mekânsal dizin ve mekânsal davranış parametreleri ile ilişkisi. Doktora Tezi, İstanbul Teknik Üniversitesi Fen Bilimleri Enstitüsü, İstanbul.

Foskett, N. H. ve Hemsley-Brown, J. (2001). Choosing futures. London: Routledge Falmer.

Gangestad, S. W., Haselton, M. G. ve Buss, D. M. (2006). Evolutionary foundations of cultural variation: Evoked culture and mate preferences. Psychological Inquiry, 17(2), 75-95.

Gati, I. ve Tal, S. (2008). Decision-making models and career guidance. (Edt. James A. Athanasou, Raoul Van Esbroeck). In International Handbook of Career Guidance. Springer Science-Business Media.

Girgin-Büyükbayraktar, Ç., Özteke, H. İ. ve Kesici, Ş. (2015). The validity and reliability study for the Turkish version of the commitment scale. The Anthropologist, 20(3), 523-534.

Guichard, J. ve Dumora, B. (2008). A constructivist approach to ethically grounded vocational development interventions for young people. (Edt. James A. Athanasou, Raoul Van Esbroeck). In International Handbook of Career Guidance. Springer Science- Business Media.

Güler, A., Halıcıoğlu, M. B. ve Taşğın, S. (2015). Sosyal bilimlerde nitel araştırma (2.Baskı). Ankara: Seçkin Yayıncılık.

Gürbüz, S. ve Şahin, F. (2017). Sosyal bilimlerde araştırma yöntemleri (4.Baskı). Ankara: Seçkin Yayıncılık. 
Hargett, J. M. (2011). Person-environment congruence and academic achievement of college students: an application of Holland's theory. Doctor of Philosophy. The University of Memphis, Memphis.

Hartung, P. J., Porfeli, E. J. ve Vondracek, F. W. (2005). Child vocational development: A review and reconsideration. Journal of Vocational Behavior 66, 385-419.

Hodkinson, P. (1998). The origins of a theory of career decision-making: A case study of hermeneutical research. British Educational Research Journal, 24(5), 557-572.

Hökelekli, H. (2015). Psikolojiye giriş (5.Baskı). Bursa: Emin Yayınları.

İstanbul Büyükşehir Belediyesi APK Daire Başkanlığı Araştırma Müdürlüğü (2004). Sosyal Doku Projesi Araştırmalart-3-Gençlik, İstanbul: Gökçe Ofset.

Kesici, Ş. (2007a). Şube rehber öğretmenlerinin görüşlerine göre 6. 7. ve 8.sınıf öğrencilerinin rehberlik ve danışma ihtiyaçları, Selçuk Üniversitesi Sosyal Bilimler Enstitüsü Dergisi, 17, 365-383.

Kesici, Ş. (2007b). Ortaöğretim öğrencilerinin anne baba tutumlarının ve rehberlik ihtiyaçlarının mesleki karar verme zorluklarını yordaması. Selçuk Üniversitesi Sosyal Bilimler Enstitüsü Dergisi, 18, 329339.

Kesici, Ş. (2008a). Sixth-, seventh, and eighth-grade students' guidance and counseling needs according to parents' views. Eurasian Journal of Educational Research, 32, 101-116.

Kesici, Ş. (2008b). A sample for guidance application of distance education technologies: A case study on graduate students' opinions about web-assisted career guidance systems. Turkish Online Journal of Distance Education, 9(1),139-156.

Kurzban, R. ve Weeden, J. (2005). Hurry Date: Mate preferences in action, Evolution and Human Behavior, 26(3), 227-244.

Mahalik, J. L. (2001). An exploration of the relationship between Holland's personality typology and personality disorder traits: a self concept perspective. Doctorate of Philosophy, Southern Illinois University, Carbondale.

McMahon, M., ve Patton, W. (2002). Using qualitative assessment in career counselling. International Journal for Educational and Vocational Guidance, 2(1), 51-66. 
Mumme, D. C. (1997). Holland's theory of vocational personalities and work environments applied to students majoring in family and consumer sciences. Doctor of philosophy, Texas Tech University, Texas.

Osipow, S. H. (1999). Assessing career indecision. Journal of Vocational Behavior, 55, 147-154.

Özdemir-Yaylacı, G. (2007). İlköğretim düzeyinde kariyer eğitimi ve danışmanlığı. Bilig, 40, 119-140.

Özteke, H. İ., Girgin-Büyükbayraktar, Ç. ve Kesici, Ş. (2015). The adaptation of romantic relationship perfectionism scale into Turkish culture. The Anthropologist, 19(2), 387-395.

Plotnik, R. (2007). Psikoloji'ye giriş (Çeviren: Tamer Geniş). İstanbul: Kaknüs Yayınları.

Redekop, F. ve Luke, C. (2014). Career development and career theory for two-year and community colleges (Edt. Grafton Eliason, Trisha Eliason, Jeff Samide, John Patrick). In career development across the lifespan. USA: Information Age Publishing, Inc.

Roberts, K. (1977). The social conditions, consequences and limitations of careers guidance. British Journal of Guidance and Counselling, 5, 1-9.

Rogers, M. E., Creed, P. A. ve Glendon, A. I. (2008). The role of personality in adolescent career planning and exploration: A social cognitive perspective. Journal of Vocational Behavior, 73, 132-142.

Roulin, N. ve Bangerter, A. (2013). Students' use of extra-curricular activities for positional advantage in competitive job markets. Journal of Education and Work, 26 (1), 21-47.

Ryan, R. M., Bernstein, J. H., ve Brown, K. W. (2010). Weekends, work, and wellbeing: Psychological need satisfactions and day of the week effects on mood, vitality, and physical symptoms. Journal of Social and Clinical Psychology, 9(1), 95-122.

Saka, N., Gati, I. ve Kelly, K. R. (2008). Emotional and personality-related aspects of career-decision-making difficulties. Journal of Career Assessment, 16(4), 403-424.

Savickas, M. L. (2001). A developmental perspective on vocational behaviour: career patterns, salience, and themes. International for educational and vocational guidance. Netherlands: Kluwer Academic Publishers, pp. 49-57. 
Savickas, M. L. (2005). The theory and practice of career construction. (Edt. Steven D. Brown \& Robert W. Lent). In Career development and counseling. Putting theory and research to work. Canada: John Wiley \& Sons, Inc, pp. 42-70.

Sugarman, L. (2005). Life-span development frameworks, accounts and strategies (Second edition). New York: Taylor \& Francis Inc. pp15-16.

Swanson, J. L., ve D'Achiardi, C. (2005). Beyond interests, needs/values, and abilities: Assessing other important career constructs over the life span (Edt. Brown, S. D., Lent, R. W.) In Career development and counseling, Putting theory and research to work. Canada: John Wiley \& Sons, Inc. pp.360.

Tavşancıl, E., ve Aslan, E. (2001). Sözel yazılı ve diğer materyaller için içerik analizi ve uygulama örnekleri. İstanbul: Epsilon Yayınları.

Tüzümen, A. ve Özdağoğlu, A. (2007). Doktora öğrencilerinin eş seçiminde önem verdikleri kriterlerin analitik hiyerarşi süreci yöntemi ile belirlenmesi. İktisadi ve İdari Bilimler Dergisi, 21(1), 215232.

Ueno, A. (2002). Career and life planning education: Investigating the meanings. Doctor of Philosophy, University of Alberta, Edmonton, Alberta.

Vinh, H. (2008). The application of Holland's theory to career counseling in Vietnam: Helping Vietnamese adolescents find their future. Master of Science, Department of Workforce Education and Development in the Graduate School, University Carbondale, Southern Illinois.

Yeşilyaprak, B. (2011). Mesleki rehberlik ve kariyer danışmanlığında paradigma değişimi ve Türkiye açısından sonuçlar: Geçmişten geleceğe yönelik bir değerlendirme. Kuram ve Uygulamada Ĕ̆itim Bilimleri, 11(4), 5-26.

Yıldırım, İ. (2007). Üniversite öğrencilerinin eş seçme kriterleri, Türk Psikolojik Danışma ve Rehberlik Dergisi, 3(27), 15-26.

Yıldırım, A. ve Şimşek, H. (2005). Sosyal bilimlerde nitel araştırma yöntemleri. Ankara: Seçkin Yayıncilık.

Zunker, V. G. (2008). Career, work, and mental health. Thousand Oaks, CA: Sage.

Zunker, V. G. (2006). Career counseling: A holistic approach (7th ed.). Belmont: Brooks/Cole Publishing. 


\section{Kaynakça Bilgisi / Citation Information}

Girrgin-Büyükbayraktar, Ç., Kesici, Ş. ve Bozgeyikli, H. (2018). Gençlerin kariyer yaşamı nasıl planlanır?. OPUS - Uluslararası Toplum Araştırmaları Dergisi, 8(Gençlik Araştırmaları Özel Sayısı), 147-169. 